\title{
Is neopterin a diagnostic marker of acute appendicitis?
}

\author{
Neopterin akut apandisit tanısında kullanılabilecek bir belirteç midir?
}

\author{
Kağan COŞKUN, ${ }^{1}$ Öner MENTEŞ, ${ }^{1}$ Ayşegül ATAK, ${ }^{2}$ Arzu ARAL, ${ }^{2}$ Mehmet ERYILMAZ, ${ }^{3}$ \\ Önder ONGURU, ${ }^{4}$ Müjdat BALKAN, ${ }^{1}$ Orhan KOZAK, ${ }^{1}$ Sadettin ÇETINER ${ }^{1}$
}

\section{BACKGROUND}

The diagnosis of acute appendicitis, even for experienced surgeons, can sometimes be complex. A delay in diagnosis increases the complication rate. This experimental study aimed to investigate the suitability and significance of neopterin as a marker for acute appendicitis.

\section{METHODS}

The levels of neopterin were measured using an acute appendicitis animal model in 35 New Zealand male rabbits. They were divided into 5 groups as Group 1= control; Group 2= sham; and Groups 3 (12-hour); 4 (24-hour); and 5 (48-hour) (based on the elapsed time period before their appendectomies). The neopterin levels of each group were measured by neopterin enzyme immunoassay kit in blood samples (taken before the appendectomies in Groups 3, 4 and 5).

\section{RESULTS}

For the diagnosis of acute appendicitis, the optimal cut-off point was $34.475 \mathrm{nmol} / \mathrm{L}$. The probability of acute appendicitis was found to be 4.667 times higher when the neopterin level was greater than $34.475 \mathrm{nmol} / \mathrm{L}$.

\section{CONCLUSION}

This study was an experimental animal study; however, it provides valuable clues useful in clinical assessment. Neopterin seems to have great potential as a new diagnostic marker for the diagnosis of acute appendicitis.

Key Words: Acute appendicitis; marker; neopterin.

\begin{abstract}
AMAÇ
Deneyimli bir cerrah için bile akut apandisit tanısı kimi zaman zor olabilir. Tanıdaki gecikme komplikasyon oran1nı arttırmaktadır. Bu deneysel çalışmadaki amacımız, akut apandisit tanısında belirteç olarak neopterinin uygunluğunun ve öneminin araştırılmasıdır.
\end{abstract}

\section{GEREÇ VE YÖNTEM}

Otuz beş adet Yeni Zellanda tipi erkek tavşanda oluşturulmuş akut apandisit modelinde neopterin düzeyleri ölçüldü. Hayvanlar apendektomi uygulanana kadar geçen zamana göre 5 gruba ayrild1. (Grup 1: Kontrol, Grup 2: Sham, Grup 3: 12. saat, Grup 4: 24. saat, Grup 5: 48. saat). Her bir gruptan alınan kan örneklerinde (Grup 3, Grup 4 ve Grup 5 'te apendektomi öncesinde) neopterin düzeyleri enzim immunoassey kitinde ölçüldü.

\section{BULGULAR}

Akut apandisit tanısı için optimal eşik değeri noktası $34,475 \mathrm{nmol} / \mathrm{lt}$ olarak saptand1. Neopterin düzeyi 34,475 nmol/lt üzerinde olduğu zaman akut apandisit olma olasıl1ğ 4,667 kat fazla olarak bulundu.

\section{SONUÇ}

Bu çalışma deneysel bir hayvan çalışması olsa da klinik uygulamalar açısından değerli ipuçları vermektedir. Neopterinin akut apandisit tanısında kullanılabilecek potansiyele sahip bir belirteç olduğunu düşünüyoruz.

Anahtar Sözcükler: Akut apandisit; belirteç; neopterin.
Acute appendicitis was first defined by Fitz in 1886. Several years later, McBurney performed the first operation for acute appendicitis. ${ }^{[1]}$ The diagnosis of acute appendicitis is routinely made using patient history and physical examination, usually with high precision. However, an ideal diagnostic test has yet to be developed. Although the gold standard treatmentappendectomy-was defined more than 100 years ago,

\footnotetext{
Departments of ${ }^{1}$ General Surgery, ${ }^{3}$ Emergency Medicine, ${ }^{4}$ Pathology, Gulhane Military Medical Faculty, Ankara;

Department of Immunology, Gazi University Faculty of Medicine, Ankara, Turkey.
} Gülhane Askeri Tıp Akademisi, ${ }^{1}$ Genel Cerrahi Anabilim Dalı,
${ }^{3}$ Acil Tip Anabilim Dalı, ${ }^{4}$ Patoloji Anabilim Dalı, Ankara; ${ }^{2}$ Gazi Üniversitesi Tıp Fakültesi, İmmünoloji Bilim Dalı, Ankara. 
surgeons are still faced with either complications related to a late diagnosis or unnecessary appendectomies, the rate of which is between 4 and $27 \%$ in different series ${ }^{[2]}$ In both cases, the morbidity and mortality, as well as the financial cost, are increased.

Neopterin [D-erythro-neopterin] is a low-molecular-weight $(253.2 \mathrm{kDa})$ aromatic pteridine molecule produced mainly by activated monocytes and macrophages, and it serves as a marker for cellular immune system activation. ${ }^{[3,4]}$ It is shown that there is an increase in the levels of neopterin with sepsis, malignancy, acute viral infections, and rheumatological diseases. ${ }^{[5]}$

In this experimental study, we aimed to investigate the suitability and importance of neopterin as a marker for acute appendicitis.

\section{MATERIALS AND METHODS}

The study was supported by the Gulhane Military Medical Academy Research Fund and was approved by the Research and Animal Ethics Committees. Thirty-five New Zealand male rabbits (weighing 2850-3200 g) were included in the study. Each animal was housed individually according to the rules of the Animal Ethics Committee.

For the study, 5 groups were constituted, with 7 rabbits in each group. Group 1 was the control group; Group 2 animals received a sham operation; Groups 3,4 , and 5 underwent appendectomies at 12 hours (h), $24 \mathrm{~h}$, and $48 \mathrm{~h}$, respectively. The induction of anesthesia in each group was through injections of $50 \mathrm{mg} /$ kg intramuscular (i.m.) ketamine (Ketalar, Eczacibaşı, İstanbul, Turkey) and $4 \mathrm{mg} / \mathrm{kg}$ i.m. xylazine (Rampun, Bayer, İstanbul, Turkey). In Groups 2, 3, 4, and 5, after the animals were anesthetized, the abdominal skin was opened with a 3-cm midline incision. In Group 1, blood samples were obtained after initiating anesthesia. In Group 2, blood samples were obtained after the sham operations.

In Groups 3, 4, and 5, the appendix was exteriorized and ligated from its base, preserving the mesentery and blood supply. Appendectomies were performed at $12 \mathrm{~h}, 24 \mathrm{~h}$, and $48 \mathrm{~h}$ for Groups 3, 4, and 5 , respectively. Blood samples were obtained before appendectomy in Groups 3, 4 and 5. The appendectomy specimens from all groups were examined histopathologically. The blood samples were centrifuged at $3000 \times \mathrm{g}$ for 15 minutes (min), and the sera separated. Serum samples were stored at $-80^{\circ} \mathrm{C}$ until the neopterin ELISA study.

We used a commercially available neopterin enzyme immunoassay kit (Neopterin ELISA, Tanı Medical Laboratories, Ankara, Turkey) for quantitative analysis of the neopterin levels in the serum samples. This neopterin assay is a competitive enzyme immu- noassay for the quantitative determination of neopterin $(\mathrm{nmol} / \mathrm{L})$ in serum, plasma and urine using a high affinity monoclonal antibody specific for neopterin. The assay was performed according to the manufacturer's instructions.

\section{Statistical Analysis}

The Kruskal-Wallis test was used to compare the differences between all groups. The Mann-Whitney U test was used for evaluating the differences between the non-appendicitis and appendicitis groups. A receiver operating characteristic curve (ROC curve) was derived by plotting sensitivity against 1 -specificity for different possible decision levels to compare the assets of the test performances. The area under the curve (AUC) was calculated using the Statistical Package for the Social Sciences (SPSS) program. The best cutoff points were selected by comparing specificities and sensitivities at various levels. The results were evaluated in mean $\pm \mathrm{SD}$ values. All $\mathrm{p}$ values $<0.05$ were considered statistically significant.

\section{RESULTS}

According to the neopterin concentrations and the obtained optical density (OD) values (at $450 \mathrm{~nm}$ ) of the standards used, intraassay validation of the assay was meaningful at $\mathrm{p}=0.0071, \mathrm{r}=-0.8903, \mathrm{r}^{2}=0.7927$. This means that the sample results were also dependable.

In Groups 3, 4, and 5, acute appendicitis was diagnosed histopathologically (Fig. 1a-c).

The mean values of neopterin levels were found to be significantly different in all groups (Table 1).

ROC curves were calculated to find the diagnostic value of neopterin. For the diagnosis of acute appendicitis, the best cutoff point was at $34.475 \mathrm{nmol} / \mathrm{L}$ (AUC=0.935) (Fig. 2), and sensitivity, specificity, positive predictive value, and negative predictive value were calculated as $87.5 \%, 100 \%, 100 \%$, and $78.57 \%$, respectively. The probability of acute appendicitis was found to be 4.667 times higher when the neopterin level was greater than $34.475 \mathrm{nmol} / \mathrm{L}$.

\section{DISCUSSION}

The diagnosis of acute appendicitis, even for experienced surgeons, can sometimes be complex. Delay

Table 1. The serum neopterin levels of the control and the study groups $(\mathrm{p}=.0001)$

\begin{tabular}{cc}
\hline Group & Neopterin $(\mathrm{nmol} / \mathrm{L})$ \\
\hline 1 & $28.18 \pm 1.74$ \\
2 & $33.56 \pm 0.75$ \\
3 & $38.16 \pm 0.81$ \\
4 & $49.10 \pm 2.63$ \\
5 & $85.87 \pm 2.48$ \\
\hline
\end{tabular}



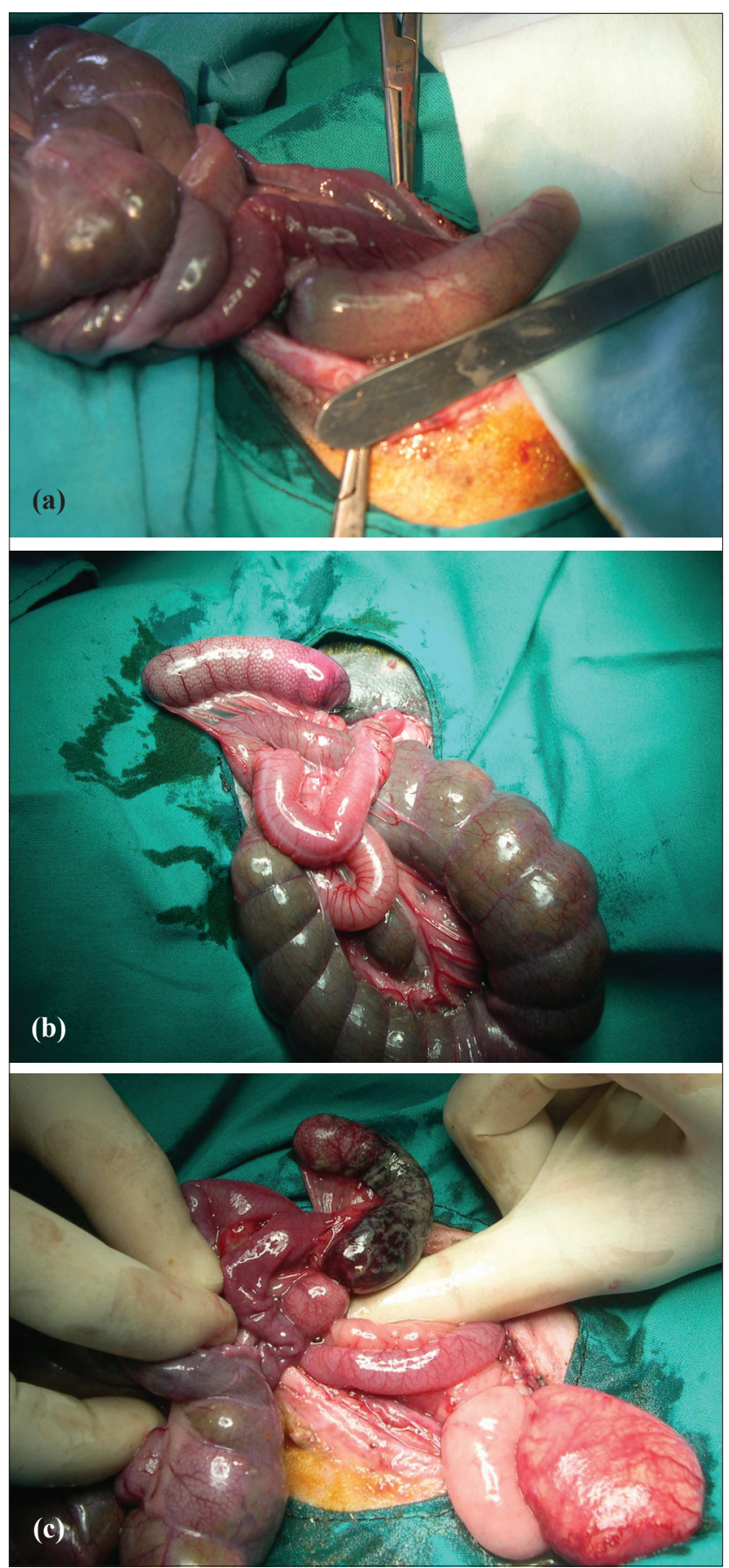

Fig. 1. An appendix, (a) $12 \mathrm{~h}$ (b) $24 \mathrm{~h}$ (c) $48 \mathrm{~h}$ after ligation from its base, preserving the mesentery and blood supply.

(Color figure can be viewed in the online issue, which is available at www.tjtes.org)

in diagnosis increases the complication rate, causing an increase in mortality and morbidity ${ }^{[6]}$ On the other hand, negative appendectomies are performed (with no appendicitis) at rates between 4 and $27 \%$ in different series. ${ }^{[2]}$ Both cases result in increased morbidity and mortality, as well as increased financial cost. In the first case, a secondary laparotomy may be needed. Every procedure that is performed during an opera- tion increases the risk of new morbidities. In the second case, unnecessary appendectomies are performed. According to Flum et al., ${ }^{[7]}$ in a nationwide analysis, 261,134 patients had appendectomies in the United States in 1997 . Of these, $15.3 \%$ were unnecessary appendectomies, resulting in a total hospital expense of approximately US $\$ 741.5$ million.

There are laboratory and radiological methods used to assist in the diagnosis of acute appendicitis. ${ }^{[8,9]}$ However, to date, neither an ideal laboratory marker nor a gold-standard radiological technique with $100 \%$ sensitivity or specificity has been found. After clinical presentation and a careful and detailed physical examination, if the surgeon still has difficulty with the diagnosis or if the case is paradoxic, a diagnostic marker with high sensitivity and specificity is required. Therefore, we aimed to investigate the potential of neopterin molecules as markers that can be used as a determinant for the diagnosis of acute appendicitis.

Neopterin is a low-molecular-weight $(253.2 \mathrm{kDa})$ aromatic molecule belonging to the group of pteridines. Neopterin, as well as other pteridines, are derived in vivo from guanosine triphosphate (GTP). The enzyme GTP-cyclohydrolase-I catalyzes this reaction in monocytes and macrophages. Neopterin is excreted by activated monocytes/macrophages, and serves as a marker for cellular immune system activation. ${ }^{[3]}$ The increase of neopterin levels in sepsis, malignancies, acute viral infections, rheumatological diseases, and in the follow-up of graft rejection has been demonstrated previously. ${ }^{[5]}$ Besides being an important marker for follow-up of graft rejection after transplantation,

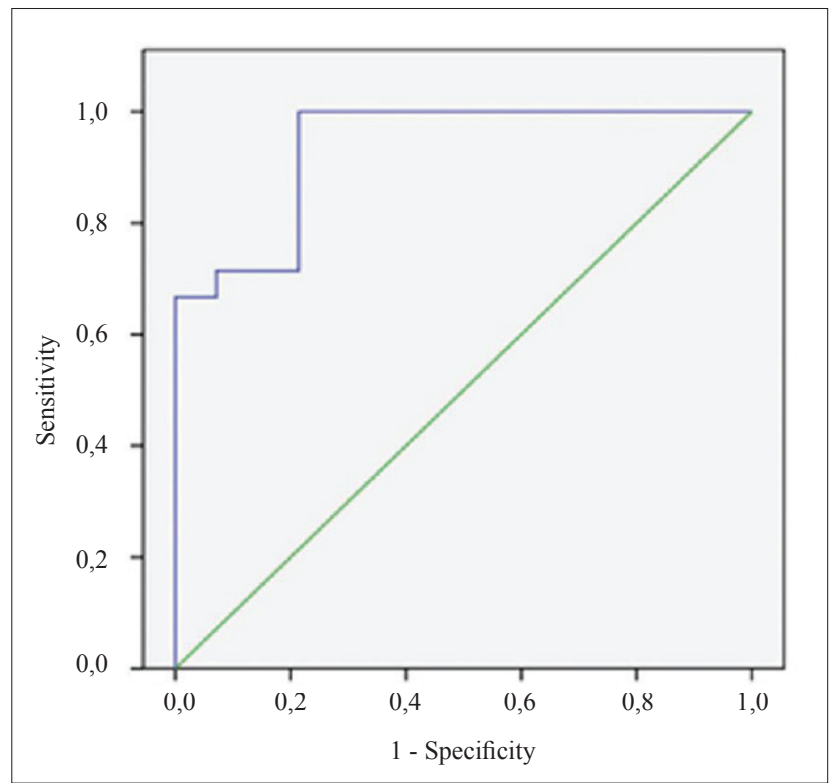

Fig. 2. The ROC plot shows the power of neopterin in the diagnosis of acute appendicitis.

(Color figure can be viewed in the online issue, which is available at www.tjtes.org) 
it is also an important marker used in protecting the recipient from infections. Since donor blood samples are not usually tested for all possible infections, the measurement of neopterin in blood donor samples is a useful tool in reducing the risk of infections via blood transfusion or transplantation. Neopterin levels may be significantly increased in some disease states compared to controls and serial measurements of neopterin levels in the same patient may be useful in order to monitor the course. Neopterin may be potentially useful for diagnostic/prognostic purposes in following up trauma and human immunodeficiency virus (HIV) patients, in early detection of graft-vshost disease in bone marrow transplantation, in early detection of graft rejection, in monitoring disease activity in autoimmune diseases, in diagnosis of viral infections, in differential diagnosis of acute viral and bacterial infections, as a prognostic indicator of malignancy, in monitoring immunostimulatory therapy, and in the follow-up of chronic infections. ${ }^{[10,11]}$ From this perspective, we studied neopterin in the diagnosis of acute appendicitis.

Several markers, such as serotonin, bilirubinemia, serum D-lactate, D-dimer, and C-reactive protein, have been studied for the diagnosis of acute appendicitis. Singh et al..$^{[12]}$ and Kalra et al. ${ }^{[13]}$ measured the serotonin level of plasma in early acute appendicitis and found that serotonin could be used as a marker at this stage. Sand et al. ${ }^{[14]}$ found that high levels of bilirubinemia and clinical symptoms related with appendicitis indicated the probability of appendiceal perforation. Duzgun et al. ${ }^{[15]}$ stated that there was a correlation between acute appendicitis and serum D-lactate levels and that these levels could be used as a diagnostic marker. Mentes et al. ${ }^{[16]}$ studied D-dimer for acute appendicitis, and found no relationship between them. However, $\mathrm{Wu}$ et al. ${ }^{[17]}$ found that C-reactive protein was a prognostic marker for early acute appendicitis. Our study also showed that neopterin is a valuable marker at 48 hours for acute appendicitis. Between 24 and 48 hours, the level of neopterin was found to be particularly significant.

In our study, the probability of acute appendicitis was found to be 4.667 times higher when the serum neopterin level was greater than $34.475 \mathrm{nmol} / \mathrm{L}$. The mean serum neopterin level of the animals in Groups 3, 4 and 5 (acute appendicitis groups) was higher than in the non-appendicitis groups, indicating that neopterin could be used as a serum marker for the diagnosis of acute appendicitis.

In conclusion, this study is an experimental animal study; however, it provides several valuable clues useful in clinical assessment. Together with a carefully extracted medical history, an accurate interpretation of the clinical presentation, and a complete physical examination, neopterin seems to have great potential as a new diagnostic marker for the diagnosis of acute appendicitis.

\section{Acknowledgements}

The authors greatly appreciate the contribution of the statistician, Mr. Ahmet Gül.

\section{REFERENCES}

1. Saidi HS, Chavda SK. Use of a modified Alvorado score in the diagnosis of acute appendicitis. E Afr Med J 2003;80:4115.

2. Jones PF. Suspected acute appendicitis: trends in management over 30 years. Br J Surg 2001;88:1570-7. CrossRef

3. Oettl K, Reibnegger G. Pteridines as inhibitors of xanthine oxidase: structural requirements. Biochim Biophys Acta 1999; 1430:387-95. CrossRef

4. Katoh S, Sueoka T, Matsuura S, Sugimoto T. Biopterin and neopterin in human saliva. Life Sci 1989;45:2561-8. CrossRef

5. Hamerlinck FFV. Neopterin: a review. Exp Dermatol 1999:8:167-76. CrossRef

6. Pegoli W. Acute appendicitis. In: Cameron JL, editor. Current surgical therapy. 6th ed. St. Louis: Mosby; 1998. p. 263-6.

7. Flum DR, Koepsell T. The clinical and economic correlates of misdiagnosed appendicitis: nationwide analysis. Arch Surg 2002;137:799-804. CrossRef

8. Roland EA, Hugander A, Ravn H, Offenbartl K, Ghazi SH, Nystrom PO, et al. Repeated clinical and laboratory examinations in patients with an equivocal diagnosis of appendicitis. World J Surg 2000;24:479-85. CrossRef

9. Michael AZ, Selzman CH, Cothren C, Sorensen AC, Raeburn CD, Harken AH. Diagnostic implications of C-reactive protein. Arch Surg 2003;138:220-4. CrossRef

10. Murr C, Widner B, Wirleitner B, Fuchs D. Neopterin as a marker for immune system activation. Curr Drug Metab 2002;3:175-87. CrossRef

11. Fuchs D, Weiss G, Reibnegger G, Wachter H. The role of neopterin as a monitor of cellular immune activation in transplantation, inflammatory, infectious and malignant diseases. Crit Rev Clin Lab Sci 1992;29:307-41. CrossRef

12. Singh MS, Dean HG, Dombel FT, Wilson DH, Flowers MW. Concentrations of serotonin in plasma-a test for appendicitis? Clin Chem 1988;34:2572-4.

13. Kalra U, Chitkara N, Dadoo RC, Singh GP, Gulati P, Narula $\mathrm{S}$. Evaluation of plasma serotonin concentration in acute appendicitis. Indian J Gastroenterol 1997;16:18-9.

14. Sand M, Bechara FG, Holland-Letz T, Sand D, Mehnert G, Mann B. Diagnostic value of hyperbilirubinemia as a predictive factor for appendiceal perforation in acute appendicitis. Am J Surg 2009;198:193-8. CrossRef

15. Duzgun AP, Bugdayci G, Sayin B, Ozmen MM, Ozer MV, Coskun F. Serum D-lactate: a useful diagnostic marker for acute appendicitis. Hepatogastroenterology 2007;54:1483-6.

16. Mentes O, Eryilmaz M, Harlak A, Ozer T, Balkan M, Kozak $\mathrm{O}$, et al. Can D-dimer become a new diagnostic parameter for acute appendicitis? Am J Emerg Med 2009;27:765-9. CrossRef

17. Wu HP, Lin CY, Chang CF, Chang YJ, Huang CY. Predictive value of C-reactive protein at different cutoff levels in acute appendicitis. Am J Emerg Med 2005;23:449-53. CrossRef 